\title{
Variability of protistan and bacterial communities in two Arctic fjords (Spitsbergen)
}

\author{
A. M.-T. Piquet $\cdot$ J. F. Scheepens $\cdot$ H. Bolhuis $\cdot$ \\ C. Wiencke • A. G. J. Buma
}

Received: 25 November 2009 / Revised: 26 May 2010 / Accepted: 28 May 2010 / Published online: 22 June 2010

(C) The Author(s) 2010. This article is published with open access at Springerlink.com

\begin{abstract}
Krossfjorden and Kongsfjorden are Arctic fjords on the western side of Spitsbergen. These fjords share a common mouth to the open sea, and both are influenced by the input of sediment-rich glacial meltwater leading to decreased surface salinity, increased turbidity and decreased light penetration during summer. Earlier classical taxonomic studies had described the pelagic protistan composition of the Kongsfjorden during summer, revealing the dominance of flagellates of often unresolved taxonomic origin. Only little information existed on microbial eukaryote composition of the Krossfjorden as well as the bacterial composition of both fjords. The aim of the present study was to analyze and compare surface summertime protistan and bacterial communities in both fjords, using molecular approaches (16S and $18 \mathrm{~S}$ rRNA DGGE, sequencing). Samples were collected three times a week from the central Kongsfjorden over a 1-month
\end{abstract}

Electronic supplementary material The online version of this article (doi:10.1007/s00300-010-0841-9) contains supplementary material, which is available to authorized users.

A. M.-T. Piquet $(\bowtie) \cdot$ J. F. Scheepens · A. G. J. Buma Department of Ocean Ecosystems, Energy and Sustainability Research Institute Groningen, University of Groningen, Kerklaan 30, 9750 AA Haren, The Netherlands e-mail: A.M.T.Piquet@rug.nl

\section{J. F. Scheepens}

Botanisches Institut der Universität Basel, Schönbeinstrasse 6, 4056 Basel, Switzerland

H. Bolhuis

Department of Marine Microbiology, Centre for Estuarine and Marine Ecology, NIOO-CEME, Korringaweg 7, 4401 NT Yerseke, The Netherlands

C. Wiencke

Alfred Wegener Institute for Polar and Marine Research, Am Handelshafen 12, 27570 Bremerhaven, Germany period. Additionally, 10 marine and 2 freshwater sites were sampled within a 1-week period in both Kongsfjorden and Krossfjorden. The central Kongsfjorden revealed a relatively stable protistan community over time with dinoflagellates, chlorophytes and small heterotrophs dominating. In contrast, the bacterial community varied over time and appeared to be correlated with the inflow of glacial meltwater. The Kongsfjorden and Krossfjorden were found to harbor distinctive bacterial and eukaryotic communities. We speculate that differences in glacial meltwater composition and fjord bathymetry affect the surface water properties and therefore the observed spatial variability in the community fingerprints.

Keywords Marine microbes - DGGE - Sequencing · Climate change $\cdot$ Meltwater $\cdot$ Polar $\cdot$ Kongsfjorden .

Krossfjorden

\section{Introduction}

Global climate change models predict enhanced glacial retreat and meltwater input in polar coastal regions. Hop et al. (2006) suggested that the Arctic-Atlantic boundary location of the Kongsfjorden and Krossfjorden (Spitsbergen) places this system in a good position as an indicator for climate-related changes. These semi-open glacial fjords share a common mouth to the open sea on the western coast of Spitsbergen. Both are influenced by meltwater of glacial origin as well as by mild temperatures mediated by the inflow of transformed Atlantic water. Krossfjorden and Kongsfjorden are fed with freshwater by, respectively, three and four major glaciers and by several streams originating from melting snowfields and glaciers located at higher elevations (Cottier et al. 2005; Svendsen et al. 2002). In the well-studied Kongsfjorden, freshwater influx 
is highest in summer and co-occurs with a strong increase in sediment particle concentrations (Somerfield et al. 2006), reaching up to $1,000 \mathrm{mg} \mathrm{dm}^{-3}$ at the glacier front (Zajaczkowski 2002). The Kongsbreen glacier sediment discharge, measured as an inverse value of light beam attenuation, appears to be responsible for the strongest sediment input in the Kongsfjorden (Keck et al. 2001; Somerfield et al. 2006). Additionally, the meltwater discharge affects the salinity of surface waters up to $45 \mathrm{~km}$ from the glacier front and up to $30 \mathrm{~m}$ depth (Hop et al. 2006; Keck et al. 2001; Svendsen et al. 2002). Hanelt et al. (2004) measured Kongsfjorden surface water salinity values varying from 24 to the normal 34 psu throughout summer.

The Kongsfjorden and Krossfjorden are also strongly influenced by the West Spitsbergen Current (WSC) of Atlantic origin that transports relatively warm saline water (psu > 34.7) northwards (Drinkwater 2006; Falk-Peterson et al. 2000; Hop et al. 2006; Keck et al. 2001; Schlichtholz and Goszczko 2006; Svendsen et al. 2002). As a result, both fjords are characterized by relatively mild temperatures when compared to other Arctic locations at similar latitude. Average water temperatures slightly above $0^{\circ} \mathrm{C}$ prevent substantial sea ice formation in winter, which is limited to the edges and inner parts of the fjords, whereas the central and outer parts remain ice-free throughout most winters (Svendsen et al. 2002).

Mixing of warm WSC water with glacial freshwater and enhanced sediment concentration are important determinants for phytoplankton growth and species composition of West Spitsbergen fjords. High sediment concentrations significantly limit light penetration into the water column, which can reduce the euphotic zone to $0.3 \mathrm{~m}$ (Keck et al. 2001) leading to unfavorable conditions for phytoplankton growth (Hop et al. 2006). Additionally, events of transformed Atlantic water inflow can affect the phytoplankton community by introducing non-Arctic species into the fjords, such as coccolithophorids (Hasle and Heimdal 1998). Similarly, strong relationships between water mass advection and changes in zooplankton community structure have already been observed in the Kongsfjorden (Willis et al. 2006).

The predicted and already observed effects of Arctic climate change require a comprehensive insight into presentday microbial community composition, as well as a better understanding of the environmental factors that determine their in situ performance. However, only a limited number of studies have been devoted to the characterization of Arctic marine prokaryotic communities in general (Bano and Hollibaugh 2002; Galand et al. 2008; Lovejoy et al. 2002, 2006; Malmstrom et al. 2007). As for the protists, classical taxonomic studies conducted on protistan diversity of the Kongsfjorden revealed a spring bloom dominated by diatoms and Phaeocystis pouchetii, followed by a more diverse summer community. Up to 134 taxa have been reported from microscopic surveys of the pelagic community from Kongsfjorden (Hasle and Heimdal 1998; Hop et al. 2002; Keck et al. 2001), but virtually no information was available on the Krossfjorden. Unfortunately, many representatives of the Kongsfjorden community are difficult to determine using classical microscopy: the cryptic morphologic features of the often tiny flagellates render their identification by microscopy extremely challenging, even for the more experienced taxonomist. Molecular techniques offer an efficient, high-resolution approach with added value to classical micro-eukaryotic community analysis. Moreover, no data had yet been published on pelagic bacterial communities from Krossfjorden, while only one study described Kongsfjorden bacterioplankton (Zeng et al. 2009) and an other the eukaryotes (Luo et al. 2009). This contrasts with the number of studies conducted at other Arctic sites (Bano and Hollibaugh 2002; Galand et al. 2008; Lovejoy et al. 2002, 2006; Malmstrom et al. 2007). Finally, simultaneous characterization of the KongsfjordenKrossfjorden surface protistan and bacterial communities was missing.

The aim of the present study was to analyze surface summertime protistan and bacterial communities as a function of environmental properties. We investigated changes in microbial communities over a 1-month period in summer for one particular location in the Kongsfjorden. We also studied spatial differences between several sampling locations in both Kongsfjorden and Krossfjorden. The microbial community composition was analyzed using $16 \mathrm{~S}$ and $18 \mathrm{~S}$ rRNA community fingerprinting and sequencing. Additionally, we explored which environmental variables correlated most strongly with the observed differences in community composition for both the temporal and the spatial study.

\section{Materials and methods}

Sampling strategy

Surface samples were collected weekly from a fixed location $\left(78^{\circ} 55.813^{\prime} \mathrm{N} 11^{\circ} 56.674^{\prime} \mathrm{E}\right.$, TS, Fig. 1) in the Kongsfjorden $200 \mathrm{~m}$ off the coast of $\mathrm{Ny}$-Ålesund from June 8th until July 8th, 2005. Additionally, to compare microbial communities between fjords, 10 marine stations and 2 freshwater stations were sampled, the latter because strongly reduced surface salinity might benefit organisms originating from freshwater sources. The samples were collected within 1 week (June 25th to July 2nd). Samples F1-F4 were taken in the Krossfjorden; F6-F8, BF (Bayelva Fjord), DD (Drinking-water Delta) in the Kongsfjorden and sample F5 were taken from a location at the intersection of the Kongsfjorden and Krossfjorden (Fig. 1). Freshwater 
was sampled from the Bayelva River (B) and the Drinkingwater Lake (D), both streaming into the Kongsfjorden (Fig. 1). Each sample was pre-filtered over a $200-\mu \mathrm{m}$ mesh and subsequently $1.5 \mathrm{~L}$ was filter-fractionated by vacuum pressure onto polycarbonate filters of $10-, 2-$ and $0.2-\mu \mathrm{m}$ pore size (Millipore). This yielded three size fractions: the $200-10-\mu \mathrm{m}, 10-2-\mu \mathrm{m}$ and $2-0.2-\mu \mathrm{m}$ fractions, henceforth named after their pore size. The filters were stored in $2-\mathrm{mL}$ screw-cap tubes at $-80^{\circ} \mathrm{C}$ until further processing.

Molecular analysis

All filter-handling steps were performed under sterile conditions. Filters were cut into small pieces, transferred to screw-cap tubes containing $1 \mathrm{~mL}$ of lysis buffer (EDTA
$40 \mathrm{mmol} \mathrm{L}^{-1}$; Tris-HCl $50 \mathrm{mmol} \mathrm{L}^{-1}$, $\mathrm{pH}$ 8.5; sucrose $0.75 \mathrm{~mol} \mathrm{~L}^{-1}$ ), thoroughly vortexed and incubated for one hour at room temperature. Given the high sediment content in several samples, DNA was extracted with the MoBio UltraClean $^{\mathrm{TM}}$ Soil DNA Kit following the manufacturer's protocol for wet soil samples applying the alternative lysis method. 18S rRNA gene fragments of approximately $500 \mathrm{bp}$ were amplified using the eukaryote-specific primer set Euk1A and 516r-GC as described by Díez et al. (2001). Primer 516r-GC contains a GC-clamp at the $5^{\prime}$-end for denaturing gradient gel electrophoresis (DGGE) application (Muyzer et al. 1993; Nübel et al. 1996). A fragment ( $\sim 430 \mathrm{bp}$ ) from the variable V6 region of bacterial $16 \mathrm{~S}$ rRNA gene was amplified using the U968f-GC forward primer, containing a GC clamp at the $5^{\prime}$ end, and the

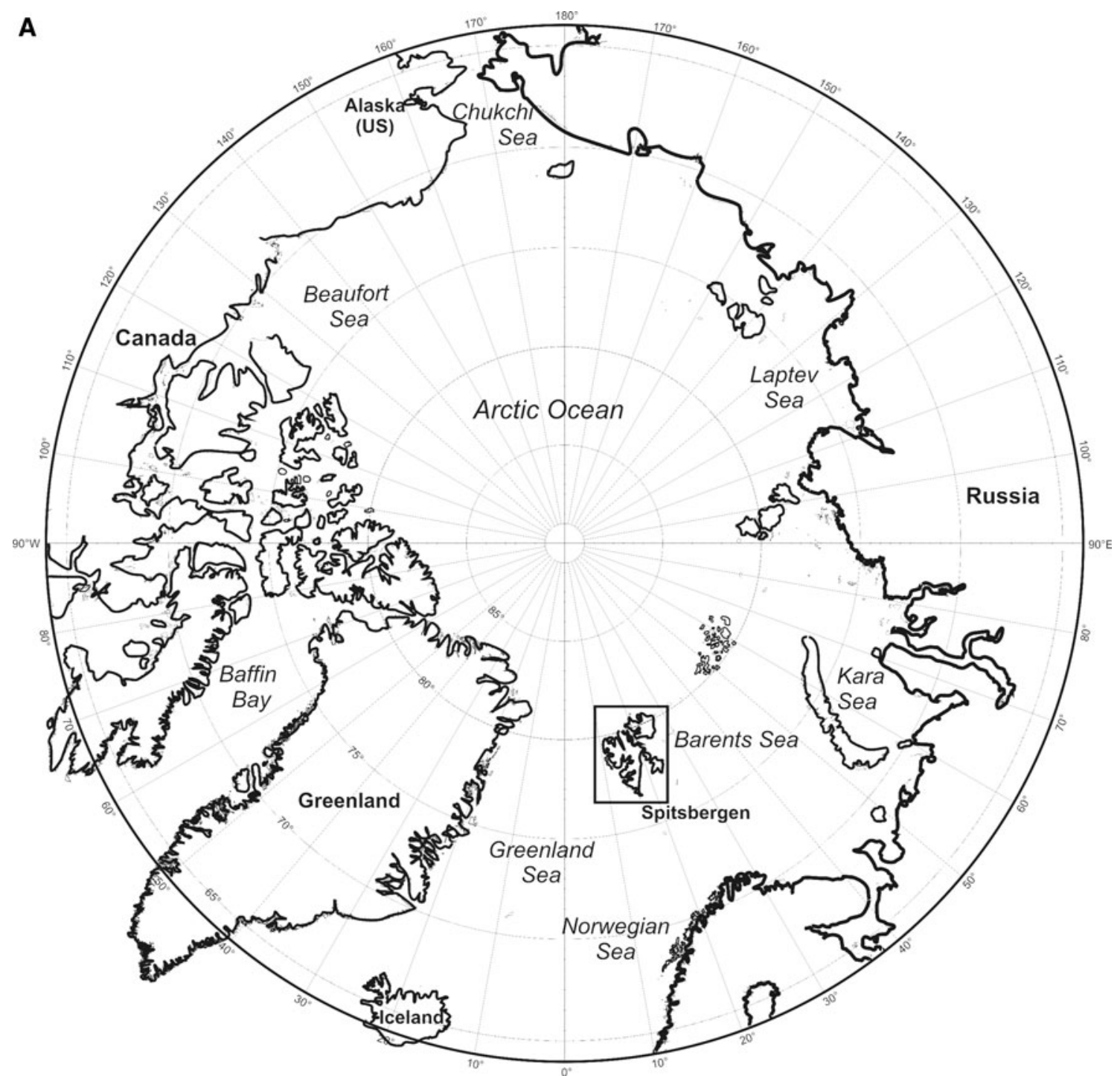

Fig. 1 a Arctic map indicating the location of Spitsbergen. b Bathymetric map of Kongsfjorden and Krossfjorden $\left(78^{\circ} 80\right.$ to $79^{\circ} 30^{\prime} \mathrm{N}$ and $11^{\circ} 30$ to $12^{\circ} 56^{\prime} \mathrm{E}$ ) with sampling locations. Samples $F 1$ to $F 4$ were collected in the Krossfjorden; $F 6-F 8, T S, B F$ and $D D$ samples col- lected in the Kongsfjorden; $F 5$ at the intersection of both fjords. $B$ and $D$ represent freshwater samples, taken, respectively, from the Bayelva River and the Drinkwater Lake 


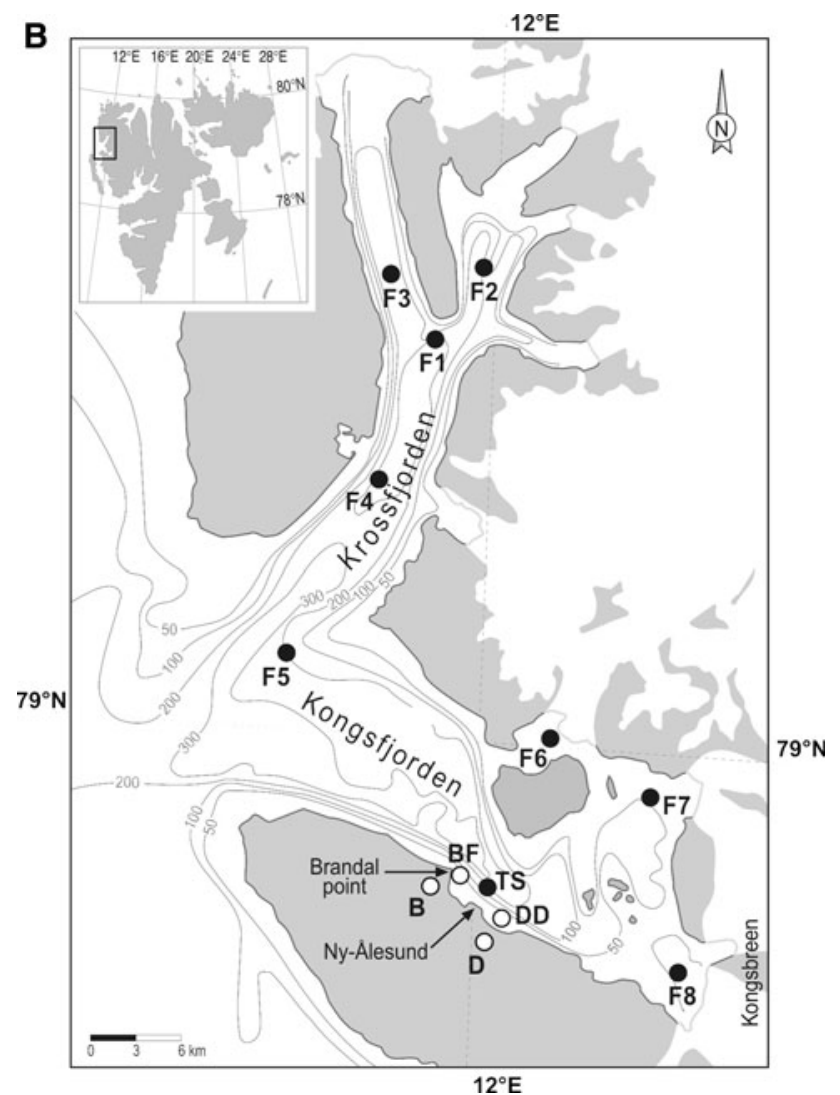

Fig. 1 continued

U1401R reverse primer (Nübel et al. 1996). The 18S rRNA polymerase chain reaction (PCR) mixture (20 $\mu \mathrm{L}$ final volume) consisted of $1 \times$ PCR buffer (Amersham), $3.25 \mathrm{mmol} \mathrm{L}^{-1}$ $\mathrm{MgCl}_{2}, 1 \%$ formamide, $0.2 \mathrm{mg} \mathrm{mL}^{-1}$ Bovine Serum Albumin (Roche), $200 \mu \mathrm{mol} \mathrm{L}^{-1}$ dNTP's, $300 \mathrm{nmol} \mathrm{L}^{-1}$ Euk1A, $300 \mathrm{nmol} \mathrm{L}^{-1}$ 516r-GC (Eurogentec) and 1U Taq-DNA polymerase (Amersham) in Ambion Ultra-clean water. For the 16S rRNA PCR reaction, the concentrations were identical except for the primers added in $200 \mathrm{nmol} \mathrm{L}^{-1}$ final concentration. The $18 \mathrm{~S}$ rRNA amplification cycle was performed as described in Díez et al. (2001). The 16S rRNA PCR started with a 5-min $94^{\circ} \mathrm{C}$ denaturation step, followed by 10 touchdown cycles with annealing temperatures decreasing from 60 to $55^{\circ} \mathrm{C}$, and then 25 cycles of $60 \mathrm{~s}$ at $94^{\circ} \mathrm{C}, 60 \mathrm{~s}$ at $55^{\circ} \mathrm{C}$ and $120 \mathrm{~s}$ at $72^{\circ} \mathrm{C}$. The amplification was finalized by an additional step at $72^{\circ} \mathrm{C}$ for $30 \mathrm{~min}$ to remove artificial double bands (Janse et al. 2004). Amplification products were analyzed by electrophoresis on a $1 \%$ $(w / v)$ agarose gel.

\section{DGGE}

PCR producing bands of the proper size and quantity were subjected to DGGE analysis using the PhorU system (Ingeny). Optimal separation for the 18S rRNA fragments was obtained with a 10-60\% urea-formamide gradient and a $40-70 \%$ gradient for the 16S rRNA fragments. For each sample, $200 \mathrm{ng}$ of PCR product was loaded with $1 \times$ loading buffer $(0.05 \% \mathrm{w} / \mathrm{v}$ bromophenol blue, $40 \% \mathrm{w} / \mathrm{v}$ sucrose, $0.1 \mathrm{~mol} \mathrm{~L}^{-1}$ EDTA $\mathrm{pH} 8.0,0.5 \%$ sodium lauryl sulfate). Analysis of the DGGE patterns was performed using BioNumerics ${ }^{\circledR}$ version 3.5 (Applied Maths). Gel images were digitalized and normalized with flanking marker samples. Automated band calling was performed in BioNumerics using standard detection settings (manufacturer's protocol); however, with a few precautions as stains in the gel may lead to false positives, and bands with low intensities may remain undetected. Consequently, a visual check of the obtained band patterns was performed in order to remove false positives and add low-intensity bands. In BioNumerics, band patterns were translated into a presence and absence matrix, and relative band intensity was inferred from densitometric curves. A matrix of distances between densitometric curves generated from the fingerprint was calculated as Pearson's product-moment correlation coefficients between patterns, using the unweighted pair group method with arithmetic averages (UPGMA). Similarities in fingerprints were presented in the form of a dendrogram.

\section{Sequencing}

A subset of the samples was chosen for cloning and sequencing such that all bands detected in the environmental fingerprints were included. Occasionally, this implicated selecting more than one size fractions for a given sample. In order to increase the informative value of the sequence set, the entire clone library-set was eventually used for sequencing and subsequent phylogenetic analysis. Clone libraries of 18S rRNA fragments (position 1-516) were generated from samples of locations: TS, F5, BF, D and B (clones were named according to location-size fraction) and of the 16S rRNA (Escherichia coli position: 968-1401) were generated from samples: F4, F8, TS, D and B. DNA fragments were cloned in pGEM-t vector (Promega) and transformed into E. coli strain JM109 according to the manufacturer's protocol. Positive inserts were selected, DNA was amplified using the DGGE primer sets and re-run on a DGGE next to their original environmental sample, in order to check accurate band mobility of these single clones. Only clones that gave DGGE-PCR products corresponding to bands in the environmental pattern were selected for subsequent sequencing. The 18S rRNA clone libraries generated from the contrasting locations F5 and $\mathrm{BF}$ proved sufficient to generate all the bands detected in marine samples from the Kongsfjorden and Krossfjorden, whereas the freshwater samples (B and DL) required more samples to generate clones representing all the bands observed in the freshwater fingerprints. The pGEM-t inserts 
were amplified from the vector's T7-SP6 sites followed by a cleanup by polyethylene glycol 8000 (Sigma) precipitation. Twenty-microliter sequence reactions were performed with Big Dye buffers and $200 \mathrm{nmol} \mathrm{L}^{-1}$ primer: T7 primer for the 16S rRNA inserts and Euk1A primer for 18S rRNA inserts. After an initial denaturation step, the sequence program consisted of 25 cycles of $10 \mathrm{~s}$ at $96^{\circ} \mathrm{C}, 5 \mathrm{~s}$ at $50^{\circ} \mathrm{C}$ and $4 \mathrm{~min}$ at $60^{\circ} \mathrm{C}$ with a final hold at $4^{\circ} \mathrm{C}$. The products were cleaned by standard isopropanol precipitation and analyzed on an automated ABI 377 DNA sequencer (Applied Biosystems).

Sequence data were manually checked with Chromas v.2.3.1, and suspected chimeric sequences were checked online using the Ribosomal Database Project II 8.1 Chimera Check program (http://rdp8.cme.msu.edu/cgis/ chimera.cgi?su=SSU). For each sequence, the closest match of a cultivated strain obtained with NCBI BLAST (http://www.ncbi.nlm.nih.gov/BLAST) was included in the phylogenetic analysis. Molecular Evolutionary Genetics Analysis (MEGA) version 4.0 (Tamura et al. 2007) and its add-in ClustalW were used to align the DNA sequences and to create neighbor-joining trees based on the maximum composite likelihood (Hartl et al. 1994; Zhu and Bustamante 2005) algorithm with 1000 bootstrap permutations (Felsenstein 1985). Operational Taxonomic Units (OTUs) were defined as sequences with at least $97 \%$ identity. In the phylogenetic tree, OTUs were classified at the taxonomic phylum and class level as deduced from sequences of known taxonomy added from the NCBI database.

Environmental variables

Solar radiation and wind speed were continuously measured by the Network for the Detection of Stratospheric Change project (Koldewey Station, AWI, Potsdam, Germany). The wind speed was measured in $\mathrm{m} \mathrm{s}^{-1}$ in an open terrain at $10 \mathrm{~m}$ height near Ny-Ålesund. The average wind speed measured on sampling days and average wind direction of the 7 days preceding each sampling day were taken for our analysis. Photosynthetically active radiation (PAR: 400-700 nm) and ultraviolet radiation (UV-R: 280$400 \mathrm{~nm}$ ) were measured in $\mathrm{W} \mathrm{m}^{-2}$ and recorded per minute. The mean incident daily irradiance was averaged over the days preceding each sampling day (7 days). Salinity was measured in Lugol-preserved surface samples (Buma et al. 2001). From each water sample $(<200 \mu \mathrm{m}), 250 \mathrm{~mL}$ was fixed with $2 \mathrm{~mL}$ Lugol and stored $\operatorname{cool}\left(4^{\circ} \mathrm{C}\right)$. In Buma et al. (2001), Lugol fixation had been shown not to significantly affect salinity measurements: variability with non-fixed samples was $<0.1 \mathrm{psu}$, which was considered acceptable for a rough estimate of freshwater input in the present study. Although we did not measure sediment content directly, visual observation was used to provide indicative indices for the sediment content of surface water ranging between 2 (turbid, brown/red coloration), 1 (intermediate turbidity) and 0 (clear, deep-blue coloration).

Data analysis

The correlation between the relative abundance of prokaryotic and eukaryotic bands and the environmental variables from location TS was estimated by calculating Spearman rank-order correlation coefficients using the software package SPSS statistics 14.0 (SPSS Inc.). Shannon-Wiener's diversity index of the cloned samples was calculated with the PAST software (PAlaeontological STatistics analysis program, http://folk.uio.no/ohammer/past/).

Ordination was performed on the absence and presence data of 62 bands of the 16S and 18S rRNA DGGE (including several unidentified bands) of ten marine samples: four from the Krossfjorden (F1-F4), five from Kongsfjorden (F6-F8, DD and BF) and the intersection location (F5), and on the values of the environmental variables location (Kongsfjorden versus Krossfjorden) and salinity. We excluded the freshwater samples from this analysis. Principal component analysis (PCA), unimodal detrended correspondence analysis (DCA) and redundancy analysis (RDA) (Van den Wollenberg 2007) calculations were made with CANOCO version 4.5.2 (Ter Braak and Šmilauer 1998). PCA is an indirect method of ordination that plots species according to the largest variation within the multivariate dataset on the $x$-axis and the second largest variation (constrained by the first axis) on the $y$-axis. In this way, the relative species locations on the plot indicate strength of similarity according to the two most explanatory dimensions of the multivariate dataset. The environmental variables that make up this multivariate dataset were added later to the plot in order to see how species and environmental variables correlate. DCA and RDA can directly test for effects of environmental variables on the species data.

Nucleotide sequence accession numbers

Sequences for each phylotype presented in this study were submitted to NCBI GenBank database under accession numbers: EU078179 to EU078273 and HM138087 to HM138193.

\section{Results}

Environmental data

Analysis of the environmental variables (Table 1) revealed that surface salinity was highly variable over time and for locations within and between the fjords. Krossfjorden 
Table 1 Environmental variables: Time (station TS) and Kongsfjorden-Krossfjorden stations (Location)

Data with a ' $\sim$ ' are average values calculated for the 7 days preceding sampling; other values were measured on the actual sampling day

\begin{tabular}{|c|c|c|c|c|c|c|c|c|c|c|}
\hline \multirow{3}{*}{\multicolumn{3}{|c|}{ Sampling date }} & \multicolumn{8}{|l|}{ Time } \\
\hline & & & \multirow{2}{*}{$\begin{array}{l}\text { Week } 1 \\
8.6 .05\end{array}$} & \multirow{2}{*}{$\begin{array}{l}\text { Week } 2 \\
15.6 .05\end{array}$} & \multirow{2}{*}{\multicolumn{2}{|c|}{$\begin{array}{l}\text { Week } 3 \\
22.6 .05\end{array}$}} & Week 4 & \multirow{2}{*}{$\begin{array}{l}\text { Week } 5 \\
6.7 .05\end{array}$} & \multirow{2}{*}{\multicolumn{2}{|c|}{$\begin{array}{l}\text { Week } 5.5 \\
8.7 .05\end{array}$}} \\
\hline & & & & & & & 29.6.05 & & & \\
\hline \multicolumn{3}{|l|}{ Salinity (psu) } & 27.3 & 33.3 & \multicolumn{2}{|c|}{30.5} & 29.2 & 20.9 & \multicolumn{2}{|c|}{22.7} \\
\hline \multicolumn{3}{|l|}{ Sediment index } & 0 & 0 & \multicolumn{2}{|c|}{0} & 2 & 2 & \multicolumn{2}{|c|}{1} \\
\hline \multicolumn{3}{|c|}{$\sim$ Sun hours $\left(\mathrm{h} \mathrm{d}^{-1)}\right.$} & 9.65 & 7.18 & \multicolumn{2}{|c|}{0.7} & 12.22 & 10.05 & \multicolumn{2}{|c|}{14.68} \\
\hline \multicolumn{3}{|c|}{$\sim$ Solar radiation $\left(\mathrm{W} \mathrm{m}^{-2}\right)$} & 236.98 & 222.68 & \multicolumn{2}{|c|}{154.53} & 265.11 & 230.56 & \multicolumn{2}{|c|}{273} \\
\hline \multicolumn{3}{|c|}{$\mathrm{UV}$ radiation $\left(\mathrm{W} \mathrm{m}^{-2}\right)$} & 12.35 & 11.63 & \multicolumn{2}{|c|}{8.77} & 12.22 & 10.8 & \multicolumn{2}{|c|}{11.69} \\
\hline \multicolumn{3}{|c|}{$\sim$ Wind speed $\left(\mathrm{m} \mathrm{s}^{-1}\right)$} & 1.04 & 2.64 & \multicolumn{2}{|c|}{3.37} & 2.65 & 2.41 & \multicolumn{2}{|c|}{3.11} \\
\hline \multirow{2}{*}{\multicolumn{3}{|c|}{$\begin{array}{l}\sim \text { Wind direction }\left(0.1^{\circ}-360.0^{\circ}\right) \\
\text { Wind direction }\left(0.1^{\circ}-360.0^{\circ}\right)\end{array}$}} & 241.57 & 220.86 & \multicolumn{2}{|c|}{193.14} & 184.31 & 172.54 & \multicolumn{2}{|c|}{249.76} \\
\hline & & & 249.18 & 153.84 & \multicolumn{2}{|c|}{268.74} & 147.22 & 125.15 & \multicolumn{2}{|c|}{207.07} \\
\hline & \multicolumn{10}{|c|}{ Location } \\
\hline & $\mathrm{F} 1$ & $\mathrm{~F} 2$ & F3 & $\mathrm{F} 4$ & F5 & F6 & F7 & F8 & $\mathrm{BF}$ & DD \\
\hline Salinity (psu) & 17.8 & 16.3 & 22.6 & 21.6 & 25.1 & 28.1 & 23.3 & 19.6 & 23.3 & 17.5 \\
\hline Sediment index & 0 & 0 & 0 & 0 & 0 & 1 & 2 & 2 & 2 & 1 \\
\hline
\end{tabular}

surface salinities were on average lower than those of the Kongsfjorden. In addition, the inner fjord locations F1, F2 and F8 from both fjords had salinities under $20 \mathrm{psu}$, except for the inner location F3 in the Krossfjorden that revealed a higher salinity (22.6). This might have been caused by the prevailing southerly winds favouring oceanic inflow on the western Krossfjorden side. The Kongsfjorden-Krossfjorden system has a complicated hydrodynamic system that still lacks thorough description, and consequently any explanation for divergent salinities remains speculative. At location TS, the surface salinity decreased over time with a strong salinity decrease after week 3 . Simultaneously, in weeks 4, 5 and 5.5 sun hours and solar irradiation were high, following a period of very overcast weather (week 3). From week 3 onwards, we observed a clear increase in sediment discharge into the Kongsfjorden. The discharge was most pronounced in weeks 4 and 5. Throughout this period, a brown/red plume of sediment-enriched water could be observed in the entire eastern side of the Kongsfjorden, up to Brandal Point (Fig. 1), for illustration, see Supplement 1. The Krossfjorden was found to be clear, despite low surface salinities.

Microbial community fingerprints from the mid-Kongsfjorden

The DGGE pattern obtained for the 18S rRNA samples collected in the mid-Kongsfjorden, at location TS, showed minor variation over time (Fig. 2a). Most DGGE bands were present in all samples regardless of the size fraction, except for one band only detected in the larger size fractions of samples taken from weeks 1 to 3 (8, 15 and 22nd of June, respectively). The strong similarity between the different size fractions is striking. Possibly, the fragility of the community at location TS might not have withstood filtration. Alternatively, the grinding effect of sediment particles could have compromised cell integrity. Yet in weeks 1 to 3 , sediment content was still low. It is therefore more likely that the eukaryotic community at site TS was fragile. Furthermore, only minor changes in relative abundance (band intensity) were observed over time. The dendrogram obtained for these samples showed a simple clustering (data not shown), where all samples had at least $93 \%$ similarity in banding pattern showing two main clusters with samples from week 4 (June 29) and the 2- and 0.2- $\mu \mathrm{m}$-size fraction samples from week 5 (July 6) clustering separately from the rest.

In contrast to the eukaryotic (18S rRNA) community, the bacterial community revealed strong variations in band patterns over the sampling period. In the first 3 weeks, only the smallest size fraction revealed a banding pattern. The smaller size fractions of weeks 1, 2 and 3 clustered together (Fig. 2b). In weeks 4 and 5, the community changed and bands were also detected in the larger size fractions. Pearson's similarity correlation revealed a high similarity (>80\%) for all size fractions of week 4 . Samples of week 4 and 5 formed a separate cluster from the other weeks. On the last sampling day 8th of July 2005 (week 5.5), the intensity and number of bands decreased together with a band pattern shift. The week 5.5 cluster showed more similarity to the cluster from the small size fraction samples of weeks 1 to 3 . This coincides with two periods characterized by no to little sediment content in surface waters, as opposed to weeks 4 and 5 .

DGGE band patterns analyzed by BioNumerics were translated into relative abundances. A total of 14 bands 


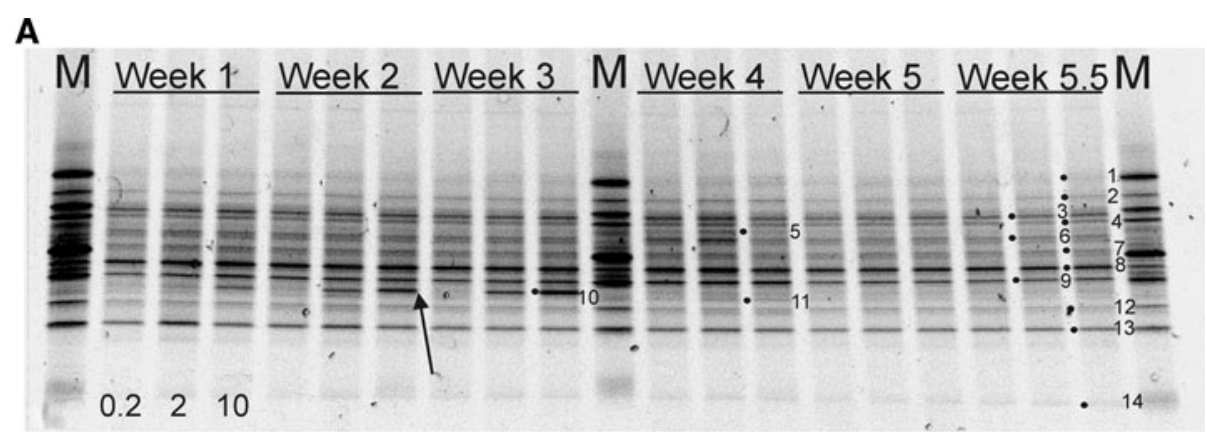

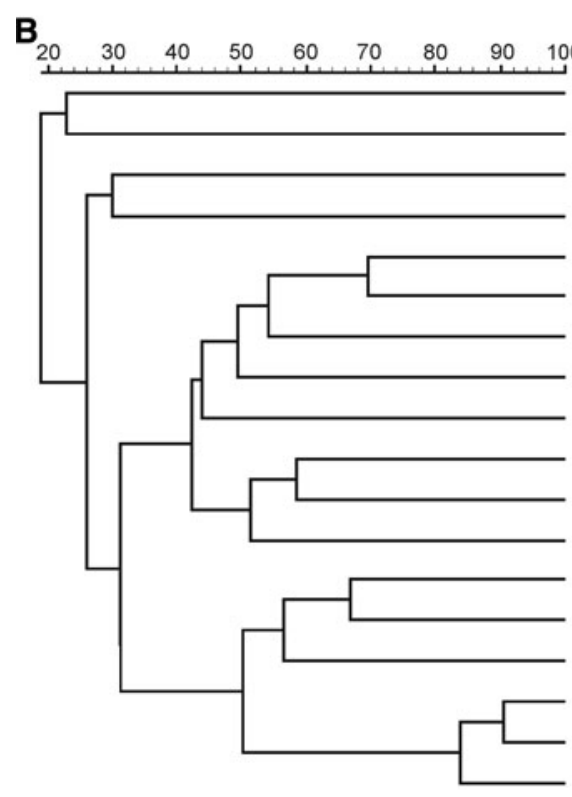

Fig. 2 Fingerprints of surface marine microbial communities from the mid-Kongsfjorden location TS collected over a 5.5-week period. a Negative image of the SybrGold-stained DGGE gel containing eukaryotic 18S rRNA fragments from location TS collected from the 8th of June until the 8th of July (specific collection dates are given in Table 1). Each sample consists of three size fractions in the order: 0.2, 2 and $10 \mu \mathrm{m}$. M, the marker sample, corresponds to sample DD-10 from the spatial study. A single band, indicated by the arrow, was only present from week 1 to 3 in the larger size fractions and disappeared in

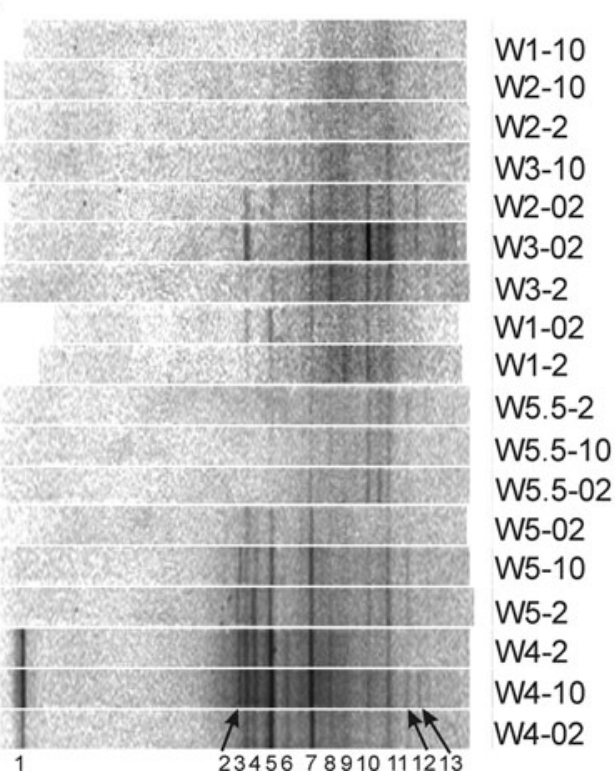

the subsequent samples. Numbers indicate bands as determined by BioNumerics and are similar to those used in the correlation analysis (BE1 to BE14). b UPGMA dendrogram based on Pearson's similarity coefficient of densitometry curves obtained for the DGGE banding pattern of the bacterial community sampled over time. Sample annotation corresponds to weeks 1 to 5.5 (W1 to W5.5) followed by the corresponding size fraction $(0.2,2$, or $10 \mu \mathrm{m})$, numbers indicate band numbers as determined by BioNumerics and are similar to those used in the correlation analysis (BP1 to BP13)

\section{Kongsfjorden-Krossfjorden comparison}

and 13 bands (BP1 to BP13; Fig. 2b) of bacterial origin were detected in the samples collected at location TS.

Pairwise Spearman rank correlation analysis of the environmental variables and relative abundance of $16 \mathrm{~S}$ and $18 \mathrm{~S}$ rRNA DGGE bands showed several significant correlations (Table 2). The variable sediment load correlated significantly with nine eukaryotic and four bacterial bands. Seven eukaryotic bands showed a negative correlation with sediment index, while three out of four of the bacterial bands showed a positive correlation. Noteworthy, the variable wind direction was significantly correlated with the relative abundance of a few bacterial and eukaryotic bands.
Cluster analysis of micro-eukaryotic community fingerprints generated for samples collected from different locations in the Kongsfjorden and Krossfjorden revealed a clustering according to size fraction and location (Fig. 3a). Five clusters became apparent. The $0.2-\mu \mathrm{m}$-size fraction of marine samples (denoted with $S$ ) grouped together, while the remaining samples revealed two different repetitive band patterns. One pattern within locations F1-F5 and another within locations F6-F8, BF and DD matched the Krossfjorden $(\mathrm{Kr})$ and Kongsfjorden $(\mathrm{Ko}+\mathrm{B})$ locations, respectively. Finally, band profiles for the freshwater 


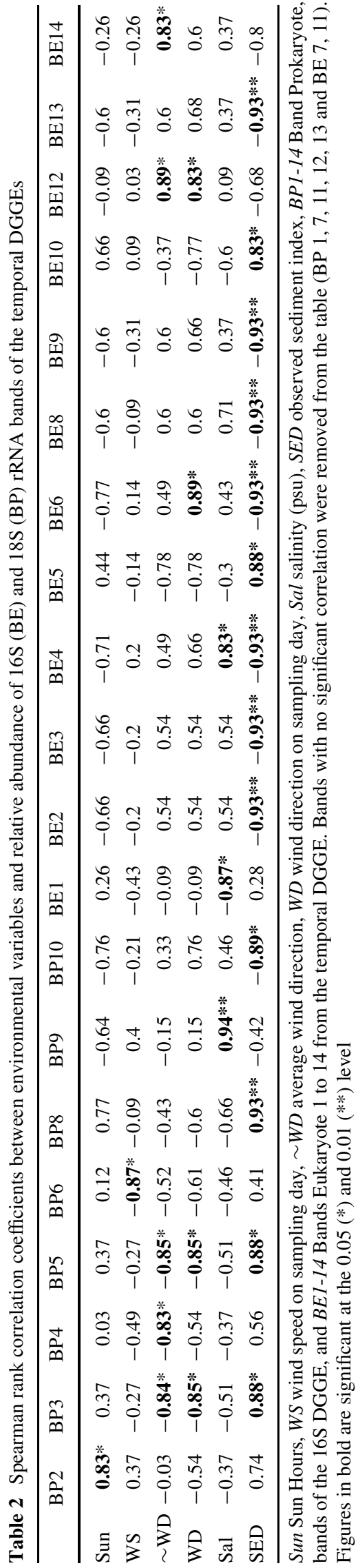

samples D and B clustered together (F) and strongly differed from the seawater samples.

Cluster analysis of bacterial community fingerprints also unveiled clustering of samples mainly according to location and size fraction (Fig. 3b). Here, freshwater samples B and D formed a distinct cluster $(\mathrm{F})$ separated from the Kongsfjorden and the Krossfjorden samples. Remarkably, 16S rRNA band patterns obtained for the samples DD and BF were more similar to the Krossfjorden than the Kongsfjorden fingerprints. Although the different size fractions appeared very similar within sampling locations in the DGGE analysis, band pattern analysis of the Krossfjorden revealed that the larger size fractions $[\mathrm{Kr}(10 \mathrm{u})]$ clustered separately from the $0.2-\mu \mathrm{m}$-size fraction $[\mathrm{Kr}(\mathrm{S})]$. In contrast, the Kongsfjorden samples mainly clustered according to location.

\section{Ordination analysis}

Detrended correspondence analysis (DCA) revealed that the length of gradients was lower than 2 . We therefore used redundancy analysis (RDA) to perform ordination analysis, as recommended by Kent and Coker (1992), on the data set generated for marine samples. The environmental variables location and salinity significantly explained $25.7 \%$ of the species variation in the data set from the marine samples (Monte Carlo permutation test, $P=0.006$ ). When the significance of the variables was tested separately, only the variable location explained a significant part of the variation (23.7\%, $P=0.009$ ). Accordingly, the PCA triplot revealed two main clusters: the Krossfjorden and Kongsfjorden samples, including the Bayelva fjord (BF) sample. The drinking-lake delta sample (DD) and F5 sample were positioned separately from the Kongsfjorden and Krossfjorden samples.

\section{Sequence data}

A total of 117 18S rRNA clones and 162 16S rRNA clones were sequenced. Phylogenetic classification of the eukaryotic sequences (Fig. 4) revealed the presence of Dinophyceae, Ciliphora, Cercozoa, Choanoflagellida, Viridiplantae, Fungi and Metazoa at the marine locations. Sequences related to Chrysophyceae, Synurophyceae and Telonema sp. were only found in freshwater samples. A few of our sequences sharing high identity were found in both freshwater and marine habitats (indicated by gray stars in Fig. 4). These sequences were related to the Dinophyceae (Gyrodinium rubrum, Gyrodinium cf. gutrula and environmental clones SCM27C4, NPK97 62-"from Kongsfjorden") and Cercozoa (Cryothecomonas sp.-related environmental clone SA2 D2 originating from a Norwegian Fjord). In our samples, Dinophyceae were the most abundant and diverse group 

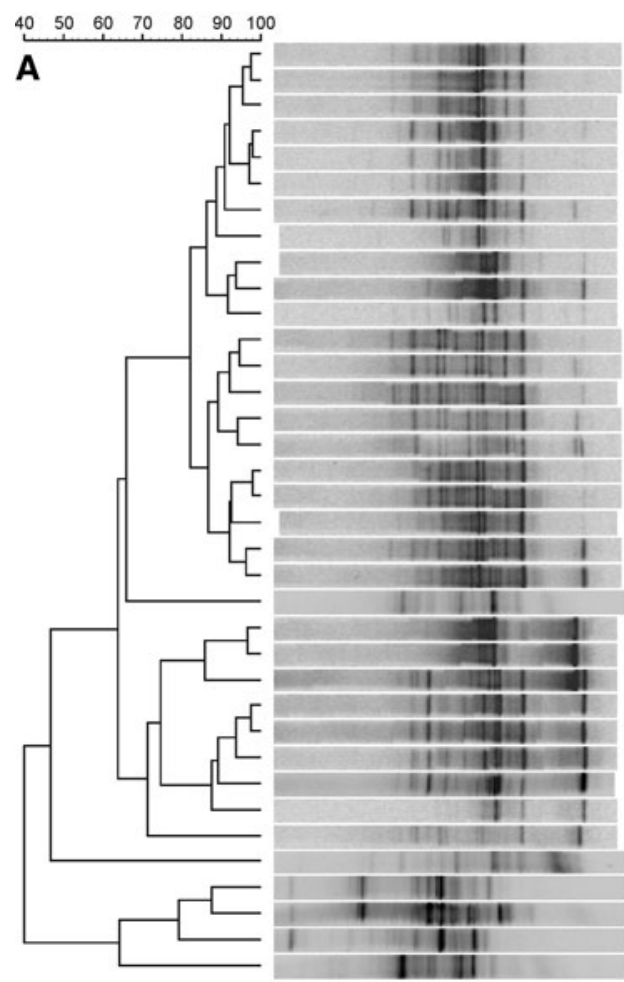

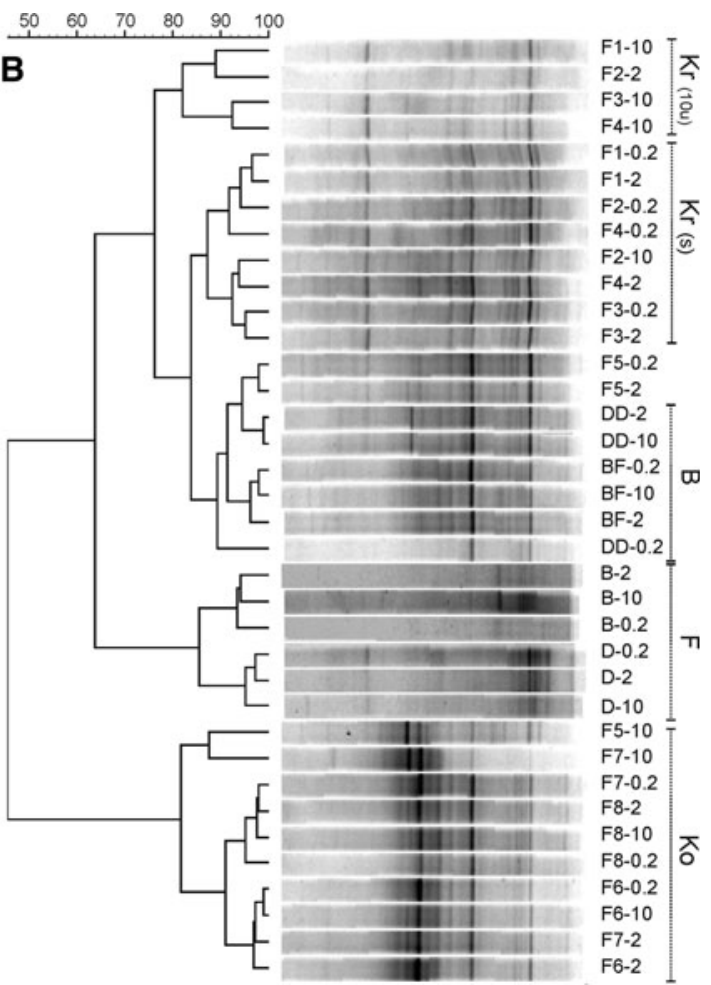

by the fraction size. Main clusters were: $F$ : freshwater; $B$ : outflow sites $B F \& D D ; S$ : small size fraction; Ko: Kongsfjorden; Kr: Krossfjorden; $K r(10 \mathrm{u})$ : Krossfjorden large size fraction; $K r(\mathrm{~S}): \mathrm{Kr}$ small size fraction with 42 sequences divided over 20 OTUs (sequences with $>99 \%$ identity).

The 16S rRNA sequences revealed the presence of Bacteroidetes (grouped under CFB), $\alpha$-Proteobacteria, $\beta$-Proteobacteria, $\gamma$-Proteobacteria and Actinobacter in both marine and freshwater samples (Fig. 5). Sequences belonging to the $\varepsilon$-Proteobacteria were only found in marine samples, while sequences of bacteria belonging to the $\delta$-Proteobacteria, Acidobacteria, Chloroflexibater, Firmicutes and Verrumicrobia were confined to freshwater samples. Thirteen sequences were related to chloroplasts and plastids, organelles of bacterial origin (Kuhsel et al. 1990), including sequences related to the Ochromonas sp. from freshwater samples and Micromonas sp. from marine samples that were also detected by $18 \mathrm{~S}$ rRNA gene sequencing. A few clones of freshwater and marine samples revealed high sequence identity: F4-19 and B2-18 ( $\beta$-Proteobacteria); F8-9b, F8-11b and B2-6b (Actinobacteria). Overall, most classes had representatives in both habitats: the $\gamma$-Proteobacteria was most diverse with 20 OTUs ( $>99 \%$ identity), followed by the $\alpha$ - and $\beta$-Proteobacteria with each 16 OTUs and the Bacteroidetes with 15 OTUs.

\section{Discussion}

High taxonomic diversity (up to 134 taxa) has been reported in the Kongsfjorden, based on microscopic surveys of the pelagic eukaryotic community (Hop et al. 2002; Keck et al. 2001). Keck et al. (2001) calculated taxonomic diversity indices of 1.4 at the outer Kongsfjorden and 3.4 near the glaciers. Although we cannot compare diversity indices obtained via different techniques, our molecular approach yielded comparable diversity indices (Shannon-Weaver) with an average of 2.5 , confirming the relatively high microbial diversity of the Kongsfjorden-Krossfjorden system.

The observed marine eukaryotic community composition was mainly dominated by members of the Alveolata and Cercozoa, which generally fits the typical sub-polar post-spring bloom as reviewed by Hop et al. (2002). Clearly, the spring bloom, usually consisting of diatoms, Phaeocystis pouchetii or Dinobryon sp. (Chrysophyceae) (Eilertsen et al. 1989; Hop et al. 2002, 2006; Keck et al. 2001), had passed. This was probably related to the early disappearance of winter sea ice in 2005. Consequently, sequences belonging to Bacillariophyceae (diatoms) and Haptophyceae (including Phaeocystis sp.) were not 

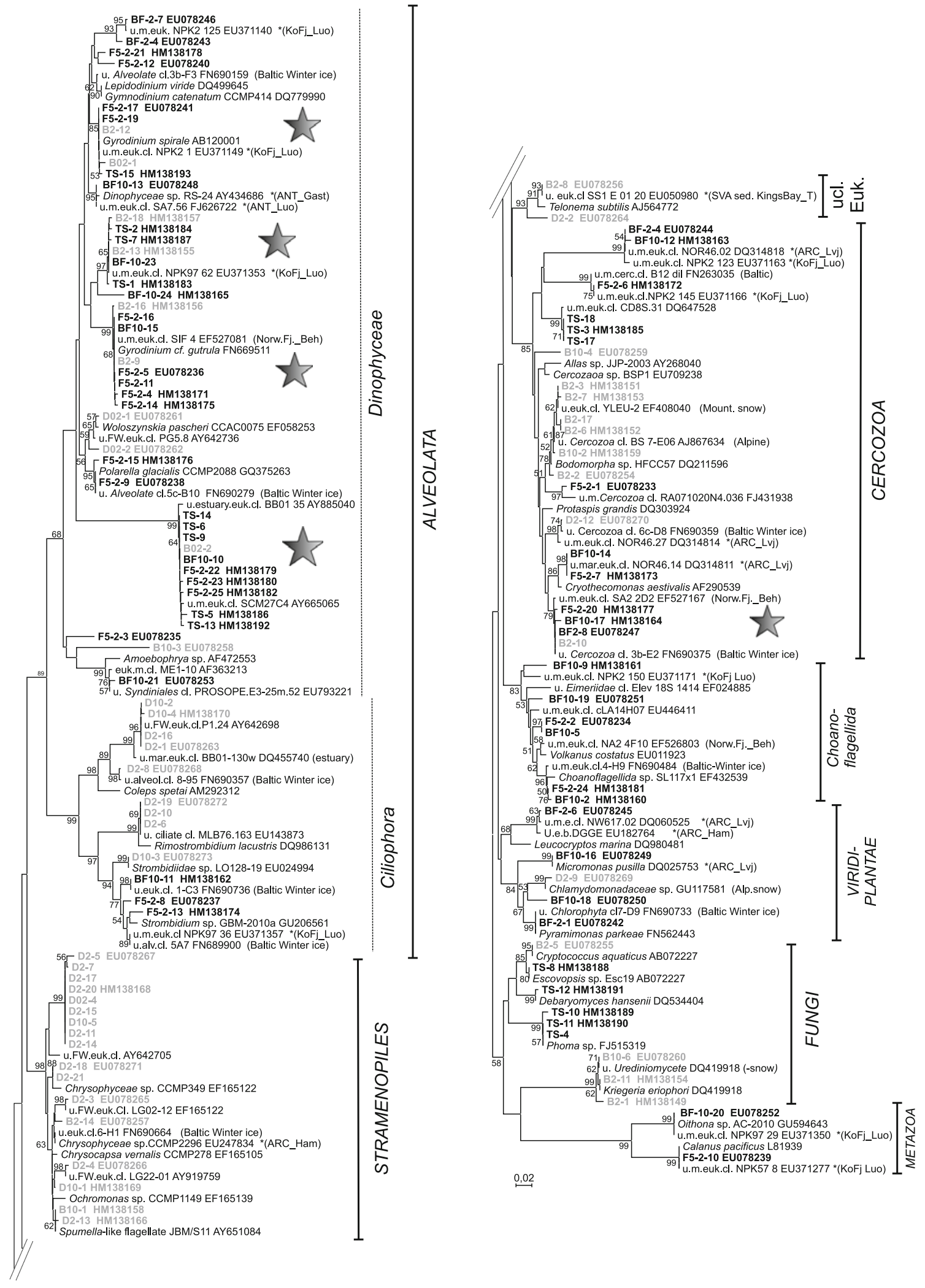
4 Fig. 4 Neighbor-joining phylogenetic tree showing the position of partial 18S rRNA sequences obtained from the generated clone libraries including best BLAST hits. The tree was constructed as a single tree but is presented in two sections for readability issues; parts where subtrees were severed from the original trees are indicated with dotted. The main classes (and families for the Alveolata) are indicated on the right-hand side of the NJ-tree. Clone-sequence names correspond to sampling location, fraction size, clone number, followed by the accession number for sequences submitted to the NCBI database. Sequences originating from marine samples are indicated in bold black fonts, sequences from freshwater samples are indicated by bold gray symbols. Bootstrap values $>50 \%$ are indicated in front of nodes. Gray stars indicate OTUs containing sequences from freshwater and marine origin. Closest environmental and isolate sequences obtained with BLAST are included in the phylogenetic tree for identification purposes. Moreover, sequences originating from polar locations are indicated by an * and information between brackets indicate the sampling location and the first author (if published). Location abbreviation specifications: ARC Arctic, ANT Antarctic, Bi-POL Bi-polar, KoFj Kongsfjorden, SVA Svalbard, NorwFj Norwegian Fjord, Mount. mountain, Alp. Alpine, sed. sediment. Authors: Luo, Gast, Lvj Lovejoy, Ham Hamilton, Beh Behnke, T Tian (Benhke et al. 2010; Gast et al. 2006; Hamilton et al. 2008; Lovejoy et al. 2006; Luo et al. 2009; Tian et al. 2008)

detected in our surface samples. Our sequencing data showed that dinoflagellate-related sequences were most abundant and diverse. These included sequences related to Gyrodinium spirale, Gymnodinium cf. gutrula, Gymnodinium catenatum, Dinophyceae sp. RS-24 and Polarella glacialis. This strong dinoflagellate dominance substantiates their proposed central role in the post-spring microbial food-web as suggested by studies conducted in the Antarctic (Díez et al. 2004; Gast et al. 2006). Interestingly, BF213 was closely related to the Dinophyceae sp. strain RS-24 isolated from the Antarctic Ross Sea (Gast et al. 2006) with 99\% similarity; over a 500-bp stretch, this strain might have a bi-polar distribution. Furthermore, our study revealed clear differences between the freshwater and marine eukaryotic communities. Stramenopiles (Chrysophyceae and Synurophyceae) and unclassified Telonema sp.-related eukaryotes were confined to the freshwater habitats. In general, clones of marine samples formed distinct clusters from the freshwater clones; however, a few exceptions were found: the Gyrodinium cf. gutrula-related OTU including F5-2-3, the Gymnodinium spirale-related OTU including F5-2-17 and the cercozoan Cryothecomonas longipes-related OTU including BF-2-8, comprised clones from the freshwater and marine habitat. The closest sequence matches revealed by BLAST queries were all from marine organisms. This suggests that the Gyrodinium sp., Gymnodinium sp. and Cryothecomonas sp. genera have closely related members found in marine and freshwater habitats, supporting our earlier suggestion that the high abundance of these genera in the marine surface samples could be related with decreased salinities as a consequence of meltwater input.
In the low nutrient, post-bloom situation, typical marine phytoplankton species might have avoided the low salinities in the surface layer as observed throughout our sampling period (Table 1). During this time, the microeukaryotic community fingerprints generated for the midKongsfjorden location were very constant, suggesting that the phytoplankton community remained dominated by species that tolerated reduced salinities. Our sequencing efforts revealed the dominance of Alveolata and Cercozoa in surface samples, which coincides with findings by Luo et al. (2009). Their glacial and sub-surface samples (2 m depth from the mid-outer Kongsfjorden) revealed a community dominated by Alveolates (excluding Metazoan sequences). Moreover, their sub-surface sample also harbored the largest proportion of Cercozoan sequences, when compared to their other water samples. Both glacial and sub-surface samples showed a high similarity in eukaryotic community composition, however, sharply contrasting with the community composition for their deeper marine samples (20$200 \mathrm{~m}$ ). There, the eukaryotic community was dominated by Stramenopiles, possibly avoiding the low-salinity surface waters. The data by Luo et al. (2009) provide support for the influence of glacial meltwater input and reduced salinity on the composition of the Kongsfjorden eukaryotic community as suggested in our study.

Contrasting with the eukaryote fingerprints, bacterial community fingerprints from the Kongsfjorden revealed variations over time that coincided with observed shifts in sediment load. Although we did not identify the bands observed in the DGGE, comparison of the microbial community fingerprint with the measured environmental variables (Table 1) suggests that the shift observed in weeks 4 and 5 might have been induced by changes in average wind direction, favouring the outflow of Bayelva sediment-rich water toward the sampling location TS. The observed increase in numbers of bands might have resulted from the introduction of bacteria attached to sediment particles, also providing an explanation for the appearance of bands in the larger size fractions in weeks 4 and 5 .

Comparison of Kongsfjorden and Krossfjorden revealed clear differences for both eukaryotes and bacteria, while communities from different locations within the same fjord remained relatively stable (Fig. 3). There are several reasons that could explain the observed differences. Although both fjords share a mouth to the open sea and are both under the influence of glacial meltwater, the presence of a bottom ridge at the outer part of the Krossfjorden (Fig. 1) might limit the inflow and increase the residence time of WSC waters in the fjord. In contrast, the Kongsfjorden has an unrestricted inflow of shelf water from the WSC and a faster turnover time (Svendsen et al. 2002). Secondly, the Krossfjorden is characterized by surface waters with a low turbidity, even when salinity is decreased. This implies that 

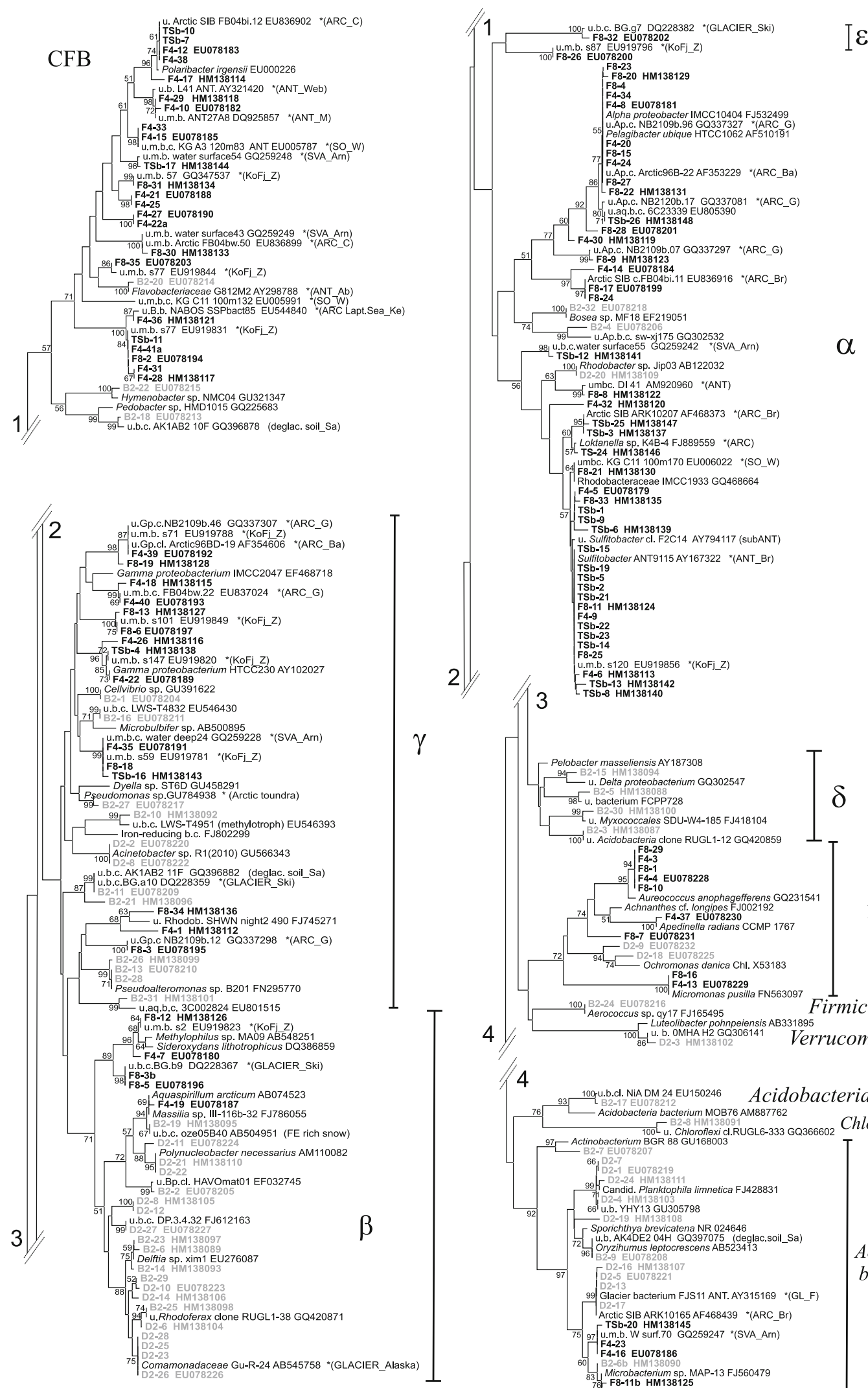

16S-like
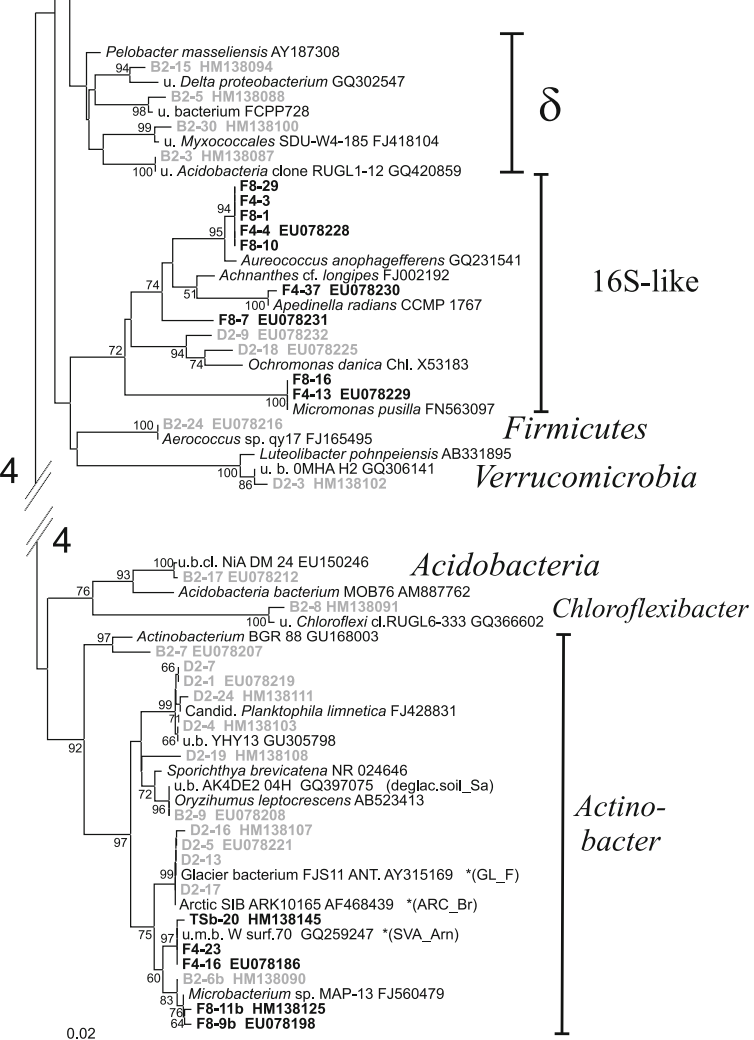
4 Fig. 5 Neighbor-joining phylogenetic tree showing the position of partial 16S rRNA sequences obtained from clone libraries generated for marine (bold black fonts) and freshwater samples (bold gray fonts), major classes are indicated on the right-hand side of the tree. The tree is presented in five sections to enhance readability, the position of the cuts are indicated by two dotted lines and identified by numbers 1 to 4 (number position: upper-left stands for the top part, lower-right position stands for the bottom-part). Location abbreviations are ARC Arctic, SVA Svalbard, KoFj Kongsfjorden, Lapt. Laptev, ANT Antarctic, sub-ANT sub-Antarctic, SO Southern Ocean, deglaci. deglaciated. Polar locations are preceded by an *. First author abbreviations: Arn Arnosti, $A b$ Abell, $B a$ Bano, $B r$ Brinkmeyer, $C$ Collin $F$ Foght, $G$ Galand, $K$ Kellogg, $M$ Murray, Sa Sattin, Ski Skidmore, $W$ West, Web Webster, ZZeng. (Abell and Bowman 2005; Arnosti 2008; Bano and Hollibaugh 2002; Brinkmeyer et al. 2003; Collins et al. 2010; Foght et al. 2004; Galand et al. 2010; Kellogg and Deming 2009; Murray and Grzymski 2007; Skidmore et al. 2005; West et al. 2008; Zeng et al. 2009; Webster et al. 2004)

sediment load is less substantial in this fjord, as opposed to the Kongsfjorden. Here, surface waters become highly turbid during the summer melting period. Thus, differences in water characteristics and sediment load could be responsible for the observed differences in microbial communities between both fjords, with differences in surface salinity being less important.

In the Kongsfjorden-Krossfjorden system, $\alpha$-Proteobacteria, including the SAR11 and RCA clusters, dominated the clone library. Moreover, members of the $\gamma$-Proteobacteria and Cytophaga-Flexibacter-Bacteroidetes (CFB) bacteria classes formed a large proportion of the clone library, which coincides with the dominant surface-water bacterioplankton groups reported by Zeng et al. (2009). Our data are also in agreement with other diversity studies conducted on marine polar bacteria (Bano and Hollibaugh 2002; Bowman et al. 2000; Morris et al. 2002). In general, many of our sequences were closely related to sequences obtained in other Arctic or Polar studies (Abell and Bowman 2005; Bano and Hollibaugh 2002; Brinkmeyer et al. 2003; Foght et al. 2004; Galand et al. 2010; Kellogg and Deming 2009; Lanoil et al. 2009; Murray and Grzymski 2007; Skidmore et al. 2005; Webster et al. 2004; West et al. 2008; Collins et al. 2010). Our sequence data showed high identity with Kongsfjorden environmental sequences reported by Zeng et al. (2009) and Svalbard environmental sequences identified by Arnosti (2008). These included 5 OTUs of the CFBs, $4 \gamma$-Proteobacteria OTUs, $1 \beta$-Proteobacteria OTU, $1 \varepsilon$-Proteobacteria OTU, $2 \alpha$-Proteobacteria OTUs and one Actinobacter OTU (as specified in Fig. 5). Several of our sequences were also closely related to environmental clones collected in the Western Arctic, notably the environmental CFB sequences ArcticFB04bw.50 and ArcticSIB FB04bi.12 (Collins et al. 2010). The latter is closely related to the typical polar Polaribacter irgensii strain. The $\gamma$-Proteobacteria comprised sequences closely related to NB2109b.12 (Galand et al. 2010), and for the $\alpha$-Proteobacteria, these included sequences related to the ubiquitous Pelagibacter ubique (with sequences from (Bano and Hollibaugh 2002; Galand et al. 2010) as well as clone NB2120b.07, which is closely related to NABOS_SSPbact67 recovered from the Laptev Sea, Eastern Arctic (Kellogg and Deming 2009). Among our environmental sequences, many were related to sequences from other Arctic or Antarctic locations, which fits the high-latitude biogeographic partitioning observed by Pommier et al. (2005).

Remarkably, we also recovered many sequences related to sequences originating from high-altitude locations (Alpine or mountain Glaciers), snow and deglaciated soils. These locations do not necessarily share similar latitudes but share harsh physical conditions and fate when temperature rises. Organisms from these locations could end up into melting streams, where we recovered some of our sequences from.

Our clone libraries also included sequences recovered from freshwater samples that were related to the Firmicutes, Verrucomicrobia, Chloroflexibacter and Acidobacteria. $\beta$-Proteobacteria generally constitute the dominant fraction of freshwater communities, while they form a minority in marine systems (Glöckner et al. 1999; Methé et al. 1998). Here, the F4-7 clone was most related to uncultivated $\beta$-Proteobacteria sequences recovered from marine systems and also identified by Zeng et al. (2009) in the Kongsfjorden. The F8-5 clone matched $\beta$-Proteobacteria sequences previously recovered from Arctic (Bench Glacier, Alaska) and West Antarctic (Kamb ice stream) subglacial systems (Skidmore et al. 2005; Lanoil et al. 2009). The closest cultivated relatives of these environmental clones (BG.b9, -h6, and KIS77) are neutrophilic iron oxidizers belonging to the Gallionella genus, suggesting that these clones represent bacteria capable of iron oxidation. The Kongsbreen glacier meltwater is a major source of reddish sediment enriched in iron oxide (S. Troelstra, pers. comm.). Overall, it is likely that F8-5 originated from Kongsbreen glacier meltwater. Moreover, it also suggests the presence of iron-oxidizing bacteria within the Kongsbreen glacial system. The freshwater sequence B2-19 was most related to sequence recovered from iron-rich snow (Kojima et al. 2009) and showed high similarity to our marine clone F4-19 ( $\beta$-Proteobacteria), also supporting the presence of bacteria with iron-oxidizing potential. Inflow of $\beta$-Proteobacteria from freshwater sources has already been reported for temperate marine sites (Crump et al. 1999; Glöckner et al. 1999). Garneau et al. (2005) studied the bacterial community composition from an Arctic coastal site influenced by the Mackenzie River, where a significant decrease in $\beta$-Proteobacteria abundance was observed in relation to increasing salinity.

So far, only a few studies have reported the presence of $\beta$-Proteobacteria from other polar marine habitats. 
Sequences related to the Nitrosomas and Nitrosospira (ammonia-oxidizing $\beta$-Proteobacteria) were described for the Arctic Ocean (Hollibaugh et al. 2002), and sequences related to the OM43 clade were recovered from the Beaufort Sea (Arctic) and the Kerguelen convergent in the Southern Ocean (Galand et al. 2008; West et al. 2008). Furthermore, sequences related to the Neisseriales (marine bacteria group I) and Burkholderiales were recovered from a coastal Antarctic site in the Ross Sea (Gentile et al. 2006). Other $\beta$-Proteobacteria were mainly recovered from Arctic and Antarctic freshwater habitats (Methé et al. 1998; Pearce et al. 2005) and from freshwater melt pools in Arctic pack ice (Brinkmeyer et al. 2004). The presence of "nonmarine" $\beta$-Proteobacteria in our marine samples indicates that glacial meltwater input is responsible for a continuous inflow of typical freshwater species that are able to survive marine surface waters at decreased salinity. In addition, the detection of F4-19, most related to $\beta$-Proteobacteria clones to sequences previously recovered from freshwater systems, from the outer Krossfjorden sampling location (F4) reveals the dispersal potential provided by meltwater outflow. Further studies are required to elucidate metabolic activity of these introduced strains in the Kongsfjorden and Krossfjorden systems.

In conclusion, we postulate that summertime microbial diversity in surface waters of the Kongsfjorden and Krossfjorden is strongly influenced by glacial melting. We furthermore suggest that decreased salinity (for eukaryotes, bacteria) and increased sediment load (bacteria) are major determinants of surface microbial community composition and diversity. While freshwater might be source of nonmarine species and simultaneously force typical marine microorganisms to deeper regions waters where they receive less light; increased sediment loads may further limit incident light required for marine primary production. Thus, changes in freshwater and sediment input resulting from increased melting of glaciers and snow/ice fields as a consequence of global warming may have a significant impact on ecosystem stability. Finally, more detailed studies are required that should include multidisciplinary approaches, including meltwater characterization and quantification, as well as metabolic studies addressing eukaryotic and bacterial strains of freshwater or glacial origin.

Acknowledgments The work was performed at the Ny-Ålesund International Arctic Environmental research and Monitoring Facility. We would like to thank Max Schwanitz, head of Koldewey scientific diving crew, for enabling us to collect all our samples. We thank the NDSC project, Koldewey station, for providing the meteorological data. We also thank Anne Hormes (2005 Koldewey Station leader) and Kingsbay for the excellent logistic support during our field work. We would finally like to thank Loes A. H. Venekamp for microscopic analysis of our samples and Dick Visser for the Kongsfjorden-Krossfjorden map. Fieldwork was financed by Alfred Wegener Institute.
Open Access This article is distributed under the terms of the Creative Commons Attribution Noncommercial License which permits any noncommercial use, distribution, and reproduction in any medium, provided the original author(s) and source are credited.

\section{References}

Abell GCJ, Bowman JP (2005) Ecological and biogeographic relationships of class Flavobacteria in the Southern Ocean. FEMS Microbiol Ecol 51:265-277

Arnosti C (2008) Functional differences between Arctic seawater and sedimentary microbial communities: contrasts in microbial hydrolysis of complex substrates. FEMS Microbiol Ecol 66:343351

Bano N, Hollibaugh JT (2002) Phylogenetic composition of bacterioplankton assemblages from the Arctic Ocean. Appl Environ Microbiol 68:505-518

Benhke A, Barger KJ, Bunge J, Stoek T (2010) Spatio-temporal variations in protistan communities along an $\mathrm{O}_{2} / \mathrm{H}_{2} \mathrm{~S}$ gradient in the anoxic Framvaren Fjord (Norway). FEMS Microbiol Ecol 72:89-102

Bowman JP, Rea SM, McCammon SA, McMeekin TA (2000) Community structure and psychrophily in Antarctic microbial ecosystems. In: Bell CR, Brylinksi M, Johnson-Green M (eds) Microbial biosystems: new frontiers. Atlantic Canada Society for Microbial Ecology, Halifax, pp 287-292

Brinkmeyer R, Knittel K, Jürgens J, Weyland H, Amann RI, Helmke E (2003) Diversity and structure of bacterial communities in Arctic versus Antarctic Pack ice. Appl Environ Microbiol 69:6610-6619

Brinkmeyer R, Glöckner F-O, Helmke E, Amann R (2004) Predominance of $\beta$-Proteobacteria in summer melt pools on Arctic pack ice. Limnol Oceanogr 49:1013-1021

Buma AGJ, de Boer MK, Boelen P (2001) Depth distribution of DNA damage in Antarctic marine phyto- and bacterioplankton exposed to summertime UV radiation. J Phycol 37:200-208

Collins RE, Rocap G, Deming JW (2010) Persistence of bacterial and archaeal communities in sea ice through an Arctic Winter. Environ Microbiol. doi: 10.1111/j.1462-2920.2010.02179.x

Cottier FR, Tverberg V, Inall ME, Svendsen H, Nilsen F, Griffiths C (2005) Water mass modification in an Arctic fjord through crossshelf exchange: the seasonal hydrography of Kongsfjorden, Svalbard. J Geophys Res 110:e12005. doi:10.1029/2004JC002757

Crump BC, Armbrust EV, Baross JA (1999) Phylogenetic analysis of particle attached and free-living bacterial communities in the Columbia River, its estuary, and the adjacent ocean. Appl Environ Microbiol 65:3192-3204

Díez B, Pedrós-Alió C, Marsh TL, Massana R (2001) Application of Denaturing Gradient Gel Electrophoresis (DGGE) to study the diversity of marine picoeukaryotic assemblages and comparison of DGGE with other molecular techniques. Appl Environ Microbiol 67:2942-2951

Díez B, Massana R, Estrada M, Pedrós-Alió C (2004) Distribution of eukaryotic picoplankton assemblages across hydrographic fronts in the Southern Ocean, studied by denaturing gradient gel electrophoresis. Limnol Oceanogr 49:1022-1034

Drinkwater KF (2006) The regime shift of the 1920s and the 1930s in the North Atlantic. Prog Oceanogr 68:134-151

Eilertsen HC, Taasen JP, Weslawski JM (1989) Phytoplankton studies in the fjords of West Spitsbergen: physical environment and production in spring and summer. J Plankton Res 11:1245-1260

Falk-Peterson S, Hop H, Budgell WP, Hegseth EN, Korsnes R, Løyning TB, Ørebæk JB, Kawamura T, Shirasawa K (2000) Physical and 
ecological processes in the marginal ice zone of the northern Barents Sea during the summer melt period. J Mar Syst 27:131-159

Felsenstein J (1985) Confidence limits on phylogenies: an approach using the bootstrap. Evolution 39:783-791

Foght J, Aislabie J, Turner S, Brown CE, Ryburn J, Saul DJ, Lawson W (2004) Culturable bacteria in subglacial sediments and ice from two southern hemisphere glaciers. Microb Ecol 47:329-340

Galand PE, Lovejoy C, Pouliot J, Garneau M-E, Vincent WF (2008) Microbial community diversity and heterotrophic production in a coastal Arctic ecosystem: a stamukhi lake and its source waters. Limnol Oceanogr 53:813-823

Galand PE, Potvin M, Casamayor EO, Lovejoy C (2010) Hydrography shapes bacterial biogeography of the deep Arctic Ocean. ISME 4:564-576

Garneau M-E, Vincent WF, Alonso-Sáez L, Gratton Y, Lovejoy C (2005) Prokaryotic community structure and heterotrophic production in a river-influences coastal arctic ecosystem. Aquat Microb Ecol 42:27-40

Gast RJ, Moran DM, Beaudoin DJ, Blythe JN, Dennett MR, Caron DA (2006) Abundance of a novel dinoflagellate phylotype in the Ross Sea, Antarctica. J Phycol 42:233-242

Gentile G, Giuliano L, D’Aurelia G, Smedile F, Azzaro M, Domenico MD, Yakimov MM (2006) Study of bacterial communities in Antarctic coastal waters by a combination of $16 \mathrm{~S}$ rRNA and $16 \mathrm{~S}$ rDNA sequencing. Environ Microbiol 8:2150-2161

Glöckner FO, Fuchs BM, Amann RI (1999) Bacterioplankton composition of lakes and oceans: a first comparison based on fluorescence in situ hybridization. Appl Environ Microbiol 65:3721-3726

Hamilton AK, Lovejoy C, Galand PE, Ingram RG (2008) Water masses and biogeography of picoeukaryote assemblages in a cold hydrographically complex system. Limnol Oceanogr 53:922-935

Hanelt D, Bischof K, Wiencke C (2004) The radiation, temperature and salinity regime in Kongsfjorden. Ber Polar- Meeresforsch 492:14-34

Hartl DL, Moriyama EN, Sawyer SA (1994) Selection intensity for codon bias. Genetics 138:227-234

Hasle GR, Heimdal BR (1998) The net phytoplankton in Kongsfjorden, Svalbard, July 1988, with general remarks on species composition of arctic phytoplankton. Polar Res 17:31-52

Hollibaugh JT, Bano N, Ducklow H (2002) Widespread distribution in polar oceans of a $16 \mathrm{~S}$ rRNA gene sequence with affinity to Nitrosospira-like ammonia-oxidizing bacteria. Appl Environ Microbiol 68:1478-1484

Hop H, Pearson T, Hegseth EN, Kovacs KM, Wiencke C, Kwasniewski $S$ et al (2002) The marine ecosystem of Kongsfjorden, in Svalbard. Polar Res 21:167-208

Hop H, Falk-Peterson S, Svendsen H, Kwasniewski S, Pavlov V, Pavlova O, Søride JE (2006) Physical and biological characteristics of the pelagic system across Fram Strait to Kongsfjorden. Prog Oceanogr 71:182-231

Janse I, Bok J, Zwart G (2004) A simple remedy against artificial double bands in DGGE. J Microbiol Methods 57:279-281

Keck A, Wiktor J, Hapter R, Nilsen R (2001) Phytoplankton assemblages related to physical gradients in an arctic, glacier-fed fjord in summer. ICES J Mar Sci 56:203-214

Kellogg C, Deming JW (2009) Comparison of free-living, suspended particle and aggregate-associated bacterial and archaeal communities in the Laptev Sea. Aquat Microb Ecol 57:1-18

Kent M, Coker P (1992) Vegetation description and analysis: a practical approach. Belhaven Press, London

Kojima H, Fukuhara H, Fukui M (2009) Community structure of microorganisms associated with reddish-brown iron-rich snow. Sys Appl Microbiol 32:429-437

Kuhsel MG, Strickland R, Palmer JD (1990) An ancient group I intron shared by Eubacteria and chloroplasts. Science 250:1570-1573
Lanoil B, Skidmore M, Priscu JC, Han S, Foo W, Vogel SW, Tulaczyk S, Engelhardt H (2009) Bacteria beneath the West Antarctic ice sheet. Environ Microbiol 11:609-615

Lovejoy C, Legendre L, Martineau M-J, Bâle J, von Quillfelt CH (2002) Distribution of phytoplankton and other protists in the North Water. Deep Sea Res Part II 49:5027-5047

Lovejoy C, Massana R, Pedrós-Alió C (2006) Diversity and distribution of marine microbial eukaryotes in the Arctic Ocean and adjacent seas. Appl Environ Microbiol 72:3085-3095

Luo W, Li H, Cai M, He J (2009) Diversity of microbial eukaryotes, Svalbard. Hydrobiologia 363:233-248

Malmstrom RR, Straza TRA, Cotrell MT, Kirchman DL (2007) Diversity, abundance, and biomass production of bacterial groups in the western Arctic Ocean. Aquat Microb Ecol 47:45-55

Methé BA, Hiorns WD, Zehr JP (1998) Contrasts between marine and freshwater bacterial community composition: analyses of communities in Lake George and six other Adirondack lakes. Limnol Oceanogr 43:368-374

Morris RM, Rappé MS, Connon SA, Vergin KL, Siebold WA, Carlson CA, Giovannoni SJ (2002) SAR11 clade dominates ocean surface bacterioplankton communities. Nature 420:806-810

Murray AE, Grzymski JJ (2007) Diversity and genomics of Antarctic marine micro-organisms. Philos Trans R Soc Lond B Biol Sci 362:2259-2271

Muyzer G, de Waal EC, Uitterlinden AG (1993) Profiling of complex microbial populations by denaturing gradient gel electrophoresis analysis of polymerase chain reaction-amplified genes coding for 16S rDNA. Appl Environ Microbiol 59:695-700

Nübel U, Engelen B, Felske A, Snaidr J, Wieshuber A, Amann RI, Ludwig W, Backhaus H (1996) Sequence heterogeneities of genes encoding 16S rRNA in Paenibacillus polymyca detected by TGGE. J Bacteriol 178:5636-5643

Pearce DA, van der Gast CJ, Woodward K, Newsham KK (2005) Significant changes in the bacterioplankton community structure of a maritime Antarctic freshwater lake following nutrient enrichment. Microbiology 151:3237-3248

Pommier T, Pinhassi J, Hagström Å (2005) Biogeographic analysis of ribosomal RNA clusters from marine bacterioplankton. Aquat Microb Ecol 41:79-89

Schlichtholz P, Goszczko I (2006) Interannual variability of the Atlantic water layer in the West Spitsbergen Current at $76.50 \mathrm{~N}$ in summer 1991-2003. Deep Sea Res Part I 53:608-626

Skidmore M, Anderson SP, Sharp M, Foght J, Lanoil B (2005) Comparison of microbial community composition of two subglacial environments reveals a possible role for microbes in chemical weathering processes. Appl Environ Microbiol 71:6986-6997

Somerfield PJ, Cochrane SJ, Dahle S, Pearson TH (2006) Free-living nematodes and macrobenthos in a high-latitude glacial fjord. $\mathrm{J}$ Exp Mar Biol Ecol 330:284-296

Svendsen H, Beszczynska-Møller A, Hagen JO, Lefauconnier B, Tverberg V, Gerland S, Ørebæk JB, Bischof K, Papucci C, Zajaczkowski M, Azzolini R, Bruland O, Wiencke C, Winther J-G, Dallman W (2002) The physical environment of the Kongsfjorden-Krossfjorden, an arctic fjord system in Svalbard. Polar Res 21:133-166

Tamura K, Dudley J, Nei M, Kumar S (2007) MEGA4: Molecular Evolutionary Genetics Analysis (MEGA) software version 4.0. Mol Biol Evol 24:1596-1599

Ter Braak CJF, Šmilauer P (1998) CANOCO reference manual and user's guide to Canoco for Windows: software for canonical community ordination (Version 4.5.2), Microcomputer Power, Ithaka

Tian F, Yu Y, Chen B, Li H, Yoa Y-F, Guo XK (2008) Bacterial, archaeal and eukaryotic diversity in Arctic sediment as revealed by $16 \mathrm{~S}$ rRNA and $18 \mathrm{~S}$ rRNA gene clone libraries analysis. Polar Biol 32:93-103 
Van den Wollenberg AL (2007) Redundancy analysis. An alternative for canonical correlation analysis. Psychometrika 42:207-219

Webster NS, Negri AP, Munro MMHG, Battershill CN (2004) Diverse microbial communities inhabit Antarctic sponges. Environ Microbiol 6:288-300

West NJ, Obernosterer I, Zemb O, Lebaron P (2008) Major differences of bacterial diversity and activity inside and outside of a natural iron-fertilized phytoplankton bloom in the Southern Ocean. Environ Microbiol 10:738-756

Willis K, Cottier F, Kwasniewski S, Wold A, Falk-Peterson S (2006) The influence of advection on zooplankton community composi- tion in an arctic fjord (Kongsfjorden, Svalbard). J Mar Syst 61:39-54

Zajaczkowski M (2002) On the use of sediment traps in sedimentation measurements in glaciated fjords. Pol Polar Res 23:161-174

Zeng Y, Zheng T, Li H (2009) Community composition of the marine bacterioplankton in Kongsfjorden (Spitsbergen) as revealed by 16S rRNA gene analysis. Polar Biol 32:1447-1460

Zhu L, Bustamante CD (2005) A composite-likelihood method for detecting directional selection from DNA sequence data. Genetics 170:1411-1421 